\title{
CORRIGENDA
}

\section{Incorporation of the bone marker carboxy-terminal telopeptide of type-1 collagen improves prognostic information of the International Staging System in newly diagnosed symptomatic multiple myeloma}

C Jakob, J Sterz, P Liebisch, M Mieth, J Rademacher, A Goerke, U Heider, C Fleissner, M Kaiser, I von Metzler, C Müller and O Sezer

Leukemia (2008) 22, 1812; doi:10.1038/leu.2008.201

Correction to: Leukemia (2008) 22, 1767-1772; doi:10.1038/leu.2008.159; published online 26 June 2008

Since the publication of their paper, the authors have identified an error in the 5-year overall survival rates for the four risk groups, which were listed incorrectly in the abstract, in the second paragraph of the Results section and in Table 4. The correct 5-year OS rates are 95, 64, 46 and $22 \%$, respectively. A revised version of Table 4 is reproduced below.

The authors apologize for any inconvenience caused.

Table 4 Comparison between ISS and combined ICTP-ISS risk score in newly diagnosed symptomatic MM

\begin{tabular}{|c|c|c|c|c|c|c|c|}
\hline \multicolumn{4}{|c|}{ Combined ISS-ICTP score } & \multicolumn{4}{|c|}{ ISS } \\
\hline Risk factors ${ }^{\mathrm{a}}$ (risk group) & $\begin{array}{c}\text { Patients } \\
\text { (\%) }\end{array}$ & 5-year OS & $\begin{array}{c}\text { Hazard ratio } \\
(95 \% \mathrm{Cl})\end{array}$ & Stage ${ }^{b}$ & $\begin{array}{c}\text { Patients } \\
\text { (\%) }\end{array}$ & 5-year OS & $\begin{array}{c}\text { Hazard ratio } \\
(95 \% \mathrm{Cl})\end{array}$ \\
\hline 0 (very low) & 21 & 95 & 1.00 (reference) & & & & \\
\hline 1 (low) & 38 & 64 & $5.78(0.72-46.27)$ & 1 & 38 & 72 & 1.00 (reference) \\
\hline 2 (intermediate) & 26 & 46 & $11.03(1.40-86.72)$ & $\|$ & 35 & 62 & $1.56(0.58-4.21)$ \\
\hline 3 (high) & 15 & 22 & $29.02(4.19-265.43)$ & III & 27 & 35 & $3.20(1.27-8.00)$ \\
\hline
\end{tabular}

Abbreviations: Cl, confidence interval; ISS, International Staging System; MM, multiple myeloma; OS, overall survival.

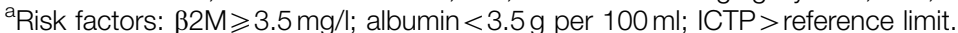

bISS I: $\beta 2 \mathrm{M}<3.5 \mathrm{mg} / \mathrm{l}$, albumin $\geqslant 3.5 \mathrm{~g}$ per $100 \mathrm{ml}$; ISS II: not stage I or III; ISS III: $\beta 2 \mathrm{M} \geqslant 5.5 \mathrm{mg} / \mathrm{l}$.

\section{Inv(11)(q21q23) fuses $M L L$ to the Notch co-activator mastermind-like 2 in secondary T-cell acute lymphoblastic leukemia}

M Metzler, MS Staege, L Harder, D Mendelova, J Zuna, E Fronkova, C Meyer, T Flohr, D Bednarova, J Harbott, T Langer, S Gesk, J Trka, R Siebert, T Dingermann, R Marschalek, C Niemeyer and W Rascher

Leukemia (2008) 22, 1812; doi:10.1038/leu.2008.104

Correction to: Leukemia (2008) 22, 1807-1811;

doi:10.1038/leu.2008.50; published online 13 March 2008

Since the publication of the above paper, the authors have detected a minor error that has no impact on the conclusion.

Please note that the second sentence of the third paragraph
'Flowcytometric analysis of the primary ALL showed common ALL phenotype with aberrant expression of CD66c, the myeloid marker CD13 and the progenitor marker CD117.' should be corrected to 'Flowcytometric analysis of the primary ALL showed common ALL phenotype with aberrant expression of CD66c and hyperdiploid DNA content (DNA index 1.17).'

The authors apologize for any inconvenience caused. 